\title{
Imaging the Salinelle Mud Volcanoes (Sicily, Italy) using integrated geophysical and geochemical surveys
}

\author{
Rosalba Napoli*, Gilda Currenti, Salvatore Giammanco, Filippo Greco, \\ Samuel Maucourant \\ Istituto Nazionale di Geofisica e Vulcanologia, Sezione di Catania, Osservatorio Etneo, Catania, Italy
}

Article history: received May 17, 2019; accepted March 17, 2020

\begin{abstract}
Geochemical and geophysical prospecting methods (including measurements of soil heat flux and soil $\mathrm{CO}_{2}$ flux, gravimetry, self-potential and geomagnetism) are used to produce an integrated data set aimed at imaging the migration of fluids in the sub-surface at the Salinelle mud volcanoes, located on the lower southwestern flank of Mt Etna (Sicily, Italy). This area was affected by magmatic eruptions from local volcanic centers between about 48 and $27 \mathrm{ka}$. Today, only pseudo-volcanic phenomena due to over-pressured multiphase pore fluids there occur. Carbon dioxide of magmatic origin, mixed with biogenic hydrocarbons, warm hypersaline waters and mud, are constantly released at the surface through the main conduits of mud volcanoes, whose activity is characterized by alternation of mild gas bubbling periods and strong paroxysmal phases. The latter produce violent gas eruptions that eject warm water $\left(\mathrm{T} \approx 50^{\circ} \mathrm{C}\right)$ to a height up to about $1 \mathrm{~m}$. Surface distribution of the geophysical and geochemical parameters have been investigated to detect the main pathways through which fluids move toward the shallow crust. Integration of geochemical, geophysical and geological maps allowed for the tracing of the fluid flow in the shallowest (a few tens of meters below the surface) part of the local hydrothermal system. Our results showed that the rising of fluids from a deep reservoir is controlled by the main structural and geological features of the area and their temporal and spatial evolution depends on pressure conditions inside the hydrothermal system.
\end{abstract}

Keywords: mud volcanoes; Mt. Etna; geophysical prospecting; $\mathrm{CO}_{2}$ efflux; hydrothermal system.

\section{Introduction}

Mud volcanoes are geological structures formed by pseudo-volcanic phenomena caused by over-pressured multiphase pore fluids, generally high-salinity water and methane gas, trapped in sedimentary basins by an impermeable top layer of rock. They are commonly associated with compressive tectonics coupled with sediment accretion at convergent margins [Kopf, 2002], where large amounts of organic material were buried at high sedimentation rates by relatively young sedimentary rocks, thus forming hydrocarbon reservoirs. Over-pressured multiphase pore fluids escape along either lithologic or structural discontinuities and through permeable rocks 


\section{Rosalba Napoli et al.}

until eventually erupt muddy liquid and gas at the surface. Mud volcano activity is generally characterized by alternating low-emission periods and strong paroxysmal phases. This activity produces typical morphological structures that vary both in their shape (ranging from conic edifices to sub-circular crater-like depressions), and in their size [Carveni et al., 2012], these features being ephemeral and easily modifiable by following emissions. Generally, mud volcano fields are covered with clays, they show no vegetation, and have diffuse salt precipitates on their surface, deposited as incrustations from evaporation of the emitted water [Etiope et al., 2002]. For this reason, in certain areas of Italy they are named Salinelle or Salse [Carveni et al., 2012], from the Italian words that mean "salt". In some cases, when the conduits of mud volcanoes get clogged by solidified material, methane accumulates pressure until exploding violently, with emission of hot, acid and/or poisonous gases. This poses a high potential risk for the people who live nearby. The most recent tragic episode of gas explosions at mud volcanoes occurred in 2014 at the Macalube of Aragona, the largest mud volcano in Sicily (with a total surface of about $1.4 \mathrm{~km}^{2}$ ) located near Agrigento (southern Sicily). A powerful explosion of mud caused by methane over-pressure killed two kids, who were buried under a thick (about $20 \mathrm{~m}$ ) cover of mud. In Sicily, mud volcanoes are quite widespread both onshore and offshore [Etiope et al., 2002; Cangemi and Madonia, 2014]. The main vents are located in the central-southern part of the island, with the exception of three groups of mud volcanoes located on the southwest flank of Mt Etna volcano, the main of which is named "Salinelle di Paternò" (Figure 1). These lay at the contact between the sedimentary rocks of the eastern margin of the Sicilian foredeep and the volcanic rocks of Mt. Etna's edifice, where an actively growing anticline is rooted at shallow depth and related to the gravitational loading and spreading of the southern flank of the volcano [Bonforte et al., 2011]. In this area, the released multiphase fluids consist of a muddy liquid and a separate gas phase. The former derives from interaction between warm hyper-saline water (originally a geothermal brine) and local clays that form the rock cover overlying the hydrocarbon reservoir [Chiodini et al., 1996; Parello et al., 2001]. The latter is a mixture, in variable proportions, of hydrocarbons (mostly methane) that accumulate in shallow pockets/reservoirs and magmatic gases (mostly carbon dioxide) that are released from the deepest levels of Mt. Etna's feeder system [Chiodini et al., 1996; Caracausi et al., 2003]. Emitted fluids have normally a temperature slightly higher than that of air, but at times, during stronger eruptions, the temperature can rise up to almost $50^{\circ} \mathrm{C}$ [Giammanco et al., 2016]. Geothermometric estimates, made using both the gas and the water chemistry, gave equilibrium temperature between 100 and $150{ }^{\circ} \mathrm{C}$ [Chiodini et al., 1996]. In this area the temporal variations in the flux of magmatic gases as well as in the temperature of water and mud would be caused by changes in the gas/magma pressure at depth beneath Mt. Etna volcano, which often precede long-standing periods of volcanic activity at Mt. Etna [Pecoraino and Giammanco, 2005; Giammanco and Bonfanti, 2009; Paonita, 2010]. The latest intense mud eruption occurred from January to June 2016. It was particularly strong, as new mud vents opened inside the courtyard of a private house located on the southern edge of the main Salinelle area and impressive mud flows invaded the surrounding streets for several hundreds of meters around. In that occasion, the regional civil protection worked to divert the mud flows into the Salinelle area in order to avoid the mud invasion in urbanized zones of the town of Paternò. Although this area has already been studied either from geochemical or from a geophysical point of view [Chiodini et al., 1986; Pecoraino and Giammanco, 2005; Giammanco et al., 2007; Panzera et al., 2016], until now no combined study was performed. Each geophysical or geochemical method has clearly different accuracy and reliability for defining different structural properties in diverse conditions and the interpretation of the phenomena includes an inherent degree of ambiguity due to the limit of each discipline. However, the ambiguity can be reduced when data are analyzed jointly. Multidisciplinary approaches of combined gas studies and geophysical surveys are well suited in the research of diffuse degassing structures [Chiodini et al., 2001; Nickschick, et al., 2015] like those of the Salinelle di Paternò, as they help defining both the mechanism of gas/fluids transport from depth to the surface, both at regional and at local scale, and the geometry of the pathways used by fluids to move through the shallow crust. Geophysical methods have greatly contributed to a better understanding of the internal structure of volcanic systems [Napoli et al 2007; Schiavone and Loddo, 2007; Blaikie et al., 2014; Maucourant et al., 2014; Napoli and Currenti, 2016] and therefore may help in the detection and investigation of the main structures (dykes, shallow fractures, cavities) that at different scales drive deep fluids in their rise towards the surface [Mauri et al., 2012]. On the other hand, both discrete and continuous geochemical measurements can provide important perspective on the dynamic state of the fluid circulation in a hydrothermal system and are well suited to monitor its spatial/temporal evolution [Pecoraino and Giammanco, 2005; Maucourant et al., 2014; Inguaggiato et al., 2018]. 


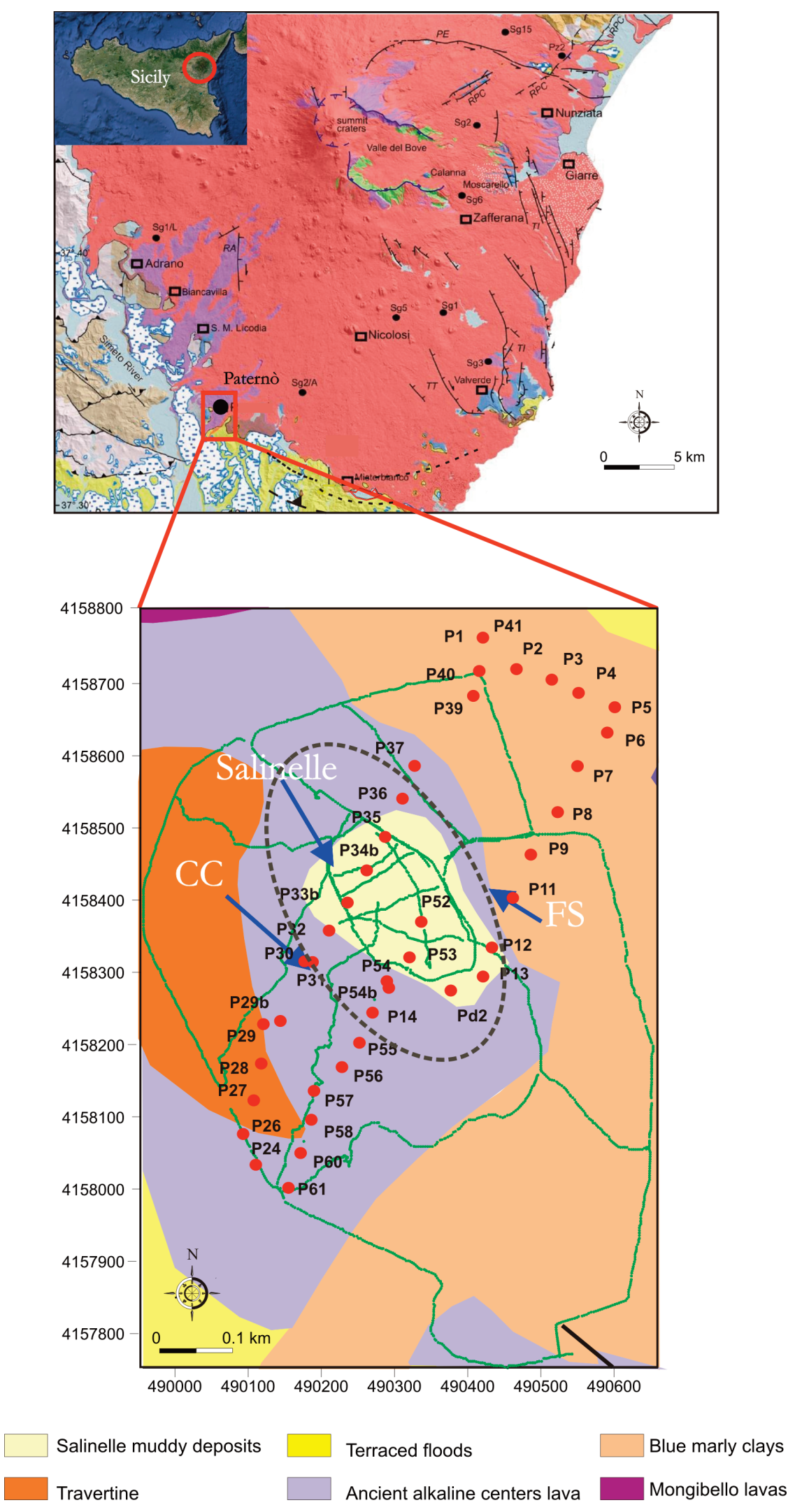

Figure 1. a) Sketch map of Etna [modified after Branca and Ferrari, 2012] showing location of the investigated area; b) simplified geological map [modified after Carveni et al 2001]; the red dots represent the measurements of soil $\mathrm{CO}_{2}$ efflux, heat flux, gravity and SP; the dashed ellipse indicates the area of the main eruptive vents. The green lines indicate magnetic measurements. FS and CC indicate the old football stadium and Conetto dei Cappuccini, respectively. 


\section{Rosalba Napoli et al.}

The studied area is characterized by localized density and magnetization contrasts due to the presence of sedimentary formations in contact with the Mt. Etna volcanics, and by fluids circulation through the shallow crust. Considering this context, we have chosen, among the geophysical methods, gravimetry and magnetic prospectings, since they are appropriate to characterize the main structural features, and the self-potential (SP) approach that is particularly suitable to monitor subsurface fluid movement [Hashimoto and Tanaka, 1995]. Therefore, geochemical, gravimetry, self-potential (SP) and magnetic surveys were simultaneously carried out in 2015 for the first time at the Salinelle di Paternò. Detailed soil $\mathrm{CO}_{2}$ flux and heat flux maps were integrated with gravimetry, SP, magnetic and geological maps, revealing the main structural features of the area and providing an overall picture of the fluid flow processes in the shallow part of the local hydrothermal system. The results encourage the design of multidisciplinary geophysical networks with high spatial/temporal resolution, in order to provide the opportunity to obtain much better comprehensive understanding of the phenomena under study and to follow their evolution with the necessary frequency of data acquisition.

\section{Geological and morphological settings}

The Salinelle mud volcanoes lay on the lower southwest flank of Mt. Etna (Figure 1), about $30 \mathrm{~km}$ away from the volcano summit craters and within the urbanized areas of Paternò village. The area rests on volcanic products of old Etnean eruptive centers (350-15 ka), in proximity of the Comiso-Messina regional fault system, that is one of the main Sicilian structural features that plays a major role in driving the Etnean magmas from the deepest reservoirs to the shallowest levels of crust [Etiope et al., 2002]. In this area, the Apennines front composed of Pleistocene sedimentary formations is in contact with the Mt. Etna volcanics [Giammanco et al., 2007]. Here, structural traps in the shallow sedimentary rocks allow for the formation of pockets of pressurized natural gas [Caracausi et al., 2003]. The gas phase is mostly composed of deep $\mathrm{CO}_{2}$ of magmatic origin, with a minor contribution of shallow hydrocarbon gases, chiefly methane [Chiodini et al., 1996; Aiuppa et al., 2004; Pecoraino and Giammanco, 2005]. The aquifer that supplies water to the mud volcanoes is part of the larger hydrogeological system of the southern flank of Mt. Etna [Aiuppa et al., 2004; Ferrara and Pappalardo 2008], where the shallow impermeable sedimentary basement prevents groundwater from reaching a considerable depth. Thinning of the impermeable Pleistocene sediments underlying Etna's volcanic rocks, as consequence of the intense local tectonics, induces upward motion of gases, with consequent mixing with mud and warm hypersaline water until reaching the surface [Aiuppa et al., 2004]. Surface emission of gas takes place from a relatively small area, located on the northern slope of a hill named Conetto dei Cappuccini (Figure 1), an old eruptive cone with associated outcrops of lava flows previously ascribed to the Ellittico Eruptive Centers [Romano et al., 1979], but recently attributed to the Piano Provenzana Formation of Ellittico Volcano, dated to about $42.1 \pm 10.4$ to $28.7 \pm 12.6$ ka [Branca et al., 2011a, 2011b]. In this area the main vents from which water, gas and mud escape are concentrated on a small space at the northern edge of the lava outcrop. Here water often ponds and gases generally gurgle more or less vigorously in nearly round pools, whose diameter ranges from a few centimeters to some meters. The proportion of mud in the erupted water is highly variable, both in space and in time. Where and when mud is the only fluid erupted together with the gas phase, conic edifices form, whose height can reach a few meters, with more or less inclined slopes and whose base diameter can be up to $10 \mathrm{~m}$ [Giammanco et al., 2007]. Especially during the summer period, the erupted mud quickly dries up and it appears completely covered by a thin layer of salt deposited through evaporation. The main eruptive vents are located in the central part of the study area and they are relatively stable both in time and in space. This area, laying on the volcanic formations, is more or less north west-south east elongated and is bounded to the north by clays and to the south by the Conetto dei Cappuccini. The main vents show only minor displacements over a very small surface (a few hundred meters, Figure 1) and fairly small changes in their shape [Federico et al., 2019], and they are characterized by a constant emission of gas and muddy water, though with variable intensity. Conversely, minor vents, especially outside of the main central eruptive area, are normally ephemeral and very unstable and they undergo marked changes over short time periods due to strong variations in the erupted gas flow. Typically, the opening of new minor vents causes extinction of older ones, with consequent formation of new mud cones and deposits, whereas erosion can strongly modify mud edifices during periods of weak or no emission of fluids. Paroxysmal phases of activity chiefly affect the main vents, although they may accompany the opening of new peripheral vents, and they may last from several days to several months. 
The emitted waters show fairly uniform and constant chemical compositions, with sodium and chlorides dominant over the other dissolved ions [Chiodini et al., 1996; D’Alessandro et al., 1996; Aiuppa et al., 2004]. They generally have an electrical conductivity of about $88 \mathrm{mS} / \mathrm{cm}$, thus higher than that of sea-water, and their $\mathrm{pH}$ is about 6.0. Water temperature at outlet generally ranges between 10 and $20^{\circ} \mathrm{C}$, but during paroxysmal phase, it may increase up to about $50^{\circ} \mathrm{C}$. Periods with higher water temperature values generally precede and/or accompany Etna eruptive activity [Giammanco et al., 1995; Giammanco and Bonfanti, 2009; Paonita, 2010]. During those anomalous periods, both the magmatic gas efflux [Giammanco et al., 2007] and the $\mathrm{CO}_{2} / \mathrm{CH}_{4}$ ratio in the emitted gas phase [Giammanco et al., 1998; Greco et al., 2016] increase as well. Geothermometric estimates indicate that the temperature of fluids, at a depth of about $1000 \mathrm{~m}$, is in the range $100-150^{\circ} \mathrm{C}$ [Chiodini et al., 1996].

\section{Geochemical surveys}

\subsection{Soil heat flux}

In order to assess both the spatial distribution and the magnitude of the heat flux in the Salinelle area, we carried out a survey for the measurement of shallow thermal conductivity and thermal gradient in soil in the same sites of the measurements of soil $\mathrm{CO}_{2}$ effluxes (Figure 1). The thermal gradient $\left(\mathrm{T}_{\mathrm{z}}\right)$ that is the soil temperature gradient along the vertical direction $\mathrm{z}(\Delta \mathrm{T} / \Delta \mathrm{z})$, was calculated measuring the temperature difference between air and soil at each site and dividing it by the depth where soil temperature measurements were carried out (in our case, $6 \mathrm{~cm}$ ). Soil thermal conductivity was measured using the non-steady-state method [Bristow et al., 1994; Bruijn et al., 1983; van Haneghem et al., 1983; van Loon et al., 1989]. For the scopes of our investigation, we used a probe (Thermal Properties Analyzer, mod. KD2, Decagon Devices, Inc., USA) consisting of a hand-held readout device and a 6-cm-long needleshaped sensor. Each measurement cycle lasts $90 \mathrm{sec}$, at the end of which a controller computes the thermal conductivity of soil based on the data acquisition during the heating and cooling periods of the probe. Based on the above input, the one-dimensional heat flux (in $\mathrm{W} \mathrm{m}^{-2}$ ) at each site was computed following the basic Fourier's law

$$
\mathrm{Q}=-\mathrm{kT}_{\mathrm{z}}
$$

where $\mathrm{k}$ is the thermal conductivity of soil. The resulting heat flux values in the studied area were in the range from 32.44 to $473.09 \mathrm{~W} \mathrm{~m}^{-2}$, with average of $163.23 \mathrm{~W} \mathrm{~m}^{-2}$ and standard deviation of $131.27 \mathrm{~W} \mathrm{~m}^{-2}$ (Figure 3a). Not surprisingly, the distribution of soil heat fluxes shows the highest values in the central part of the study area around the main eruptive vents. Other high values were measured in the SW part of the study area around the Conetto dei Cappuccini hill, therefore close to the place where some months later the strong 2016 mud eruption occurred. No anomalies were instead observed in the northern and eastern parts of the study area, in correspondence of the marly clays outcrops.

\subsection{Soil $\mathrm{CO}_{2}$ efflux}

Gas emissions in the Salinelle area are mostly focused at the many degassing vents, but a significant part of total degassing occurs also in diffuse form through soil principally in the areas surrounding the main vents, though with a lesser magnitude. Soil $\mathrm{CO}_{2}$ effluxes were measured in 40 sites distributed along two NNE-SSW parallel profiles over an area of $\sim 0.12 \mathrm{~km}^{2}$ (Figure 1). The proximity of the survey to inhabited or cultivated areas prevented the extension of the survey to the south-east and north-west areas, so we could not have a regularly spaced grid of measurement points. Anyway, the profiles were chosen so as to intersect the area affected by the main emission vents, whose location can be considered fairly stable over time [Federico et al., 2019]. The method used was that of the accumulation chamber [Parkinson, 1981; Tonani and Miele, 1991; Chiodini et al., 1998]. Details on the instrumental setup used in the studied area can be found in Greco et al. [2016].

Measured $\mathrm{CO}_{2}$ effluxes ranged from 0.3 to $299.3 \mathrm{~g} \mathrm{~m}^{-2} \mathrm{~d}^{-1}$ (Table 1), with average value of $37.5 \mathrm{~g} \mathrm{~m}^{-2} \mathrm{~d}^{-1}$ and standard deviation of $55.9 \mathrm{~g} \mathrm{~m}^{-2} \mathrm{~d}^{-1}$ (Figure $3 \mathrm{~b}$ ). Due to the nature of this parameter, whose spatial dispersion follows a lognormal distribution [Ahrens, 1954], all $\mathrm{CO}_{2}$ data were transformed into their corresponding $\log _{10}$ values before being processed and mapped. The distribution map of the $\mathrm{CO}_{2}$ efflux values shows some similarities 


\section{Rosalba Napoli et al.}

to that of soil heat fluxes, because the highest degassing values were found near the main eruptive vents in the central part of the study area and in some points of its SW portion. However, some other points located just south of the main vents and at the NE corner of the area showed high $\mathrm{CO}_{2}$ effluxes but, conversely, very low heat fluxes.

\begin{tabular}{|c|c|c|c|c|c|}
\hline Name & Latitude N (m) & Longitute E (m) & $\mathrm{SP}(\mathrm{mV})$ & $\begin{array}{c}\mathrm{CO}_{2} \text { efflux } \\
\left(\mathrm{gm}^{-2} \mathrm{~d}^{-1}\right)\end{array}$ & $\begin{array}{c}\text { Heat Flux } \\
\left(\mathrm{W} \mathrm{m} \mathrm{m}^{-2}\right)\end{array}$ \\
\hline P1 & 4158787 & 490425 & 0.73 & 17.52 & 49.02 \\
\hline $\mathrm{P} 2$ & 4158760 & 490465 & -25.1 & 15.12 & 42.02 \\
\hline P3 & 4158739 & 490517 & -8.35 & 5.04 & 59.52 \\
\hline $\mathrm{P} 4$ & 4158722 & 490560 & 12.75 & 9.6 & 70.33 \\
\hline P5 & 4158701 & 490599 & 5.4 & 112.32 & 103.99 \\
\hline P6 & 4158667 & 490586 & 10.5 & 49.872 & 139.85 \\
\hline P7 & 4158624 & 490554 & 12.7 & 29.76 & 46.82 \\
\hline P8 & 4158559 & 490525 & 6.57 & 23.28 & 67.22 \\
\hline P9 & 4158495 & 490485 & 24.6 & 3.552 & 65.36 \\
\hline P11 & 4158437 & 490464 & 2.08 & 1.656 & 43.35 \\
\hline P12 & 4158394 & 490441 & 22.8 & 39.744 & 113.57 \\
\hline P13 & 4158332 & 490422 & -1.085 & 18.96 & 40.96 \\
\hline P14 & 4158313 & 490378 & 13.8 & 16.704 & 78.43 \\
\hline $\mathrm{Pd} 2$ & 4158347 & 490387 & 0.32 & n.m. & n.m. \\
\hline P24 & 4158074 & 490107 & -3.77 & 0.312 & 32.45 \\
\hline P26 & 4158118 & 490088 & -5.9 & 21.6 & 359.86 \\
\hline P27 & 4158165 & 490105 & 1.8 & 77.016 & 243.19 \\
\hline P28 & 4158215 & 490118 & 14 & 10.992 & 40.81 \\
\hline P29 & 4158269 & 490120 & -9.1 & 7.68 & 252.59 \\
\hline $\mathrm{P} 29 \mathrm{~b}$ & 4158273 & 490143 & 14.5 & 22.32 & 150.99 \\
\hline P30 & 4158355 & 490189 & -1.03 & 10.992 & 293.36 \\
\hline P31 & 4158356 & 490180 & -7.3 & 4.44 & 137.13 \\
\hline P32 & 4158398 & 490212 & -8.8 & 17.04 & 275.82 \\
\hline P33 & 4158438 & 490234 & -2.075 & 3 & 369.38 \\
\hline P34 & 4158482 & 490262 & 0.15 & 10.992 & 326.72 \\
\hline P34b & 4158482 & 490262 & 2.6 & n.m. & n.m. \\
\hline P35 & 4158523 & 490287 & 40.54 & 7.776 & 63.99 \\
\hline P36 & 4158579 & 490312 & -17.93 & 39 & 130.7 \\
\hline P37 & 4158625 & 490329 & -27.07 & 3.552 & 39.01 \\
\hline P39 & 4158723 & 490411 & 11.08 & 20.88 & 36.81 \\
\hline $\mathrm{P} 40$ & 4158757 & 490419 & -3.45 & 17.112 & 34.48 \\
\hline P41 & 4158790 & 490427 & -5.1 & n.m. & n.m. \\
\hline P52 & 4158408 & 490338 & -11.48 & 141.072 & 473.09 \\
\hline P53 & 4158361 & 490322 & -10.81 & 29.208 & 452.5 \\
\hline P54 & 4158325 & 490291 & -14.23 & 7.68 & 47.47 \\
\hline $\mathrm{P} 54 \mathrm{~b}$ & 4158338 & 490293 & -11.97 & 299.28 & 369.88 \\
\hline P55 & 4158285 & 490271 & -20.26 & 40.32 & 351.68 \\
\hline P56 & 4158245 & 490254 & -18.1 & 86.16 & 308.31 \\
\hline P57 & 4158209 & 490230 & 1.9 & 163.44 & 97.57 \\
\hline P58 & 4158180 & 490190 & 0.1 & 29.664 & 70.03 \\
\hline P59 & 415813 & 490185 & 12.5 & 75.12 & 127.45 \\
\hline P60 & 4158091 & 490170 & 16.3 & 26.88 & 229.58 \\
\hline P61 & 4158042 & 490151 & 9 & 16.2 & 186.97 \\
\hline
\end{tabular}

Table 1. Results of the 2015 survey; n.m. = not measured. 


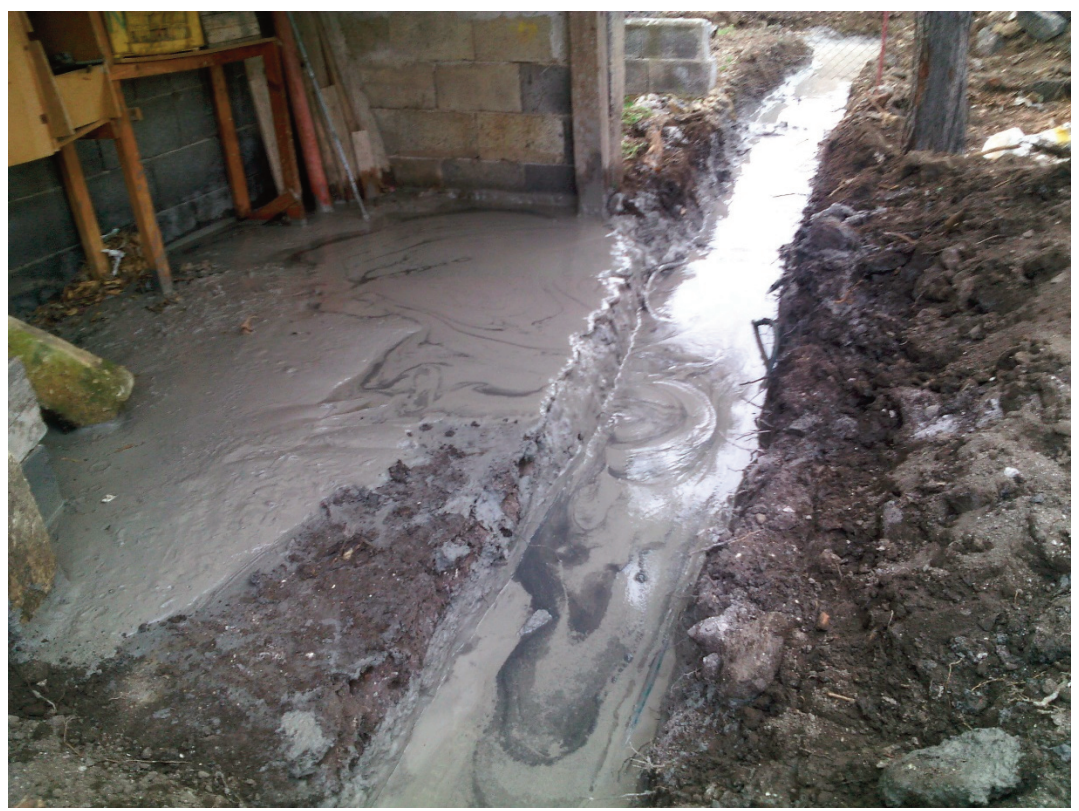

Figure 2. Image of the 2016 mud eruption at the Salinelle. The picture shows a detail of the private house invaded by the mud with a small channel dug by the Civil Protection in order to drain the mud out of the property.

\section{Geophysical surveys}

\subsection{Gravity}

Gravity data were simultaneously gathered with the measurements of soil $\mathrm{CO}_{2}$ effluxes and heat flux in the same sites (Figure 1). The instrument used was a portable Scintrex CG5 gravimeter. We also established a reference station in the investigated area, linked with the absolute gravity station in Catania, located about 20 km away, where the FG5\#238 absolute gravimeter is routinely used [Pistorio et al., 2011; Greco et al., 2012]. In order to achieve a reliable daily instrumental drift, we performed measurements at the reference station every 2 hours, so that we could get at least four readings during a working day. Measurements started from the reference station and at least three readings were taken and averaged at each measurement point of the surveyed area, obtaining an accuracy of $10 \mu \mathrm{Gal}$. Spatial coordinates of each gravity points were determined using traditional terrestrial measurements and data analysis. The precision achieved for both horizontal and vertical coordinates is in the order of few centimeters. Consequently, due to the uncertainty in the elevation data, the maximum error in gravity determinations is lower than $0.5 \mathrm{mGal}$.

Gravity readings were corrected for instrumental drift and adjusted for tidal effects using the Eterna 3.4 software [Wenzel, 1996]. Subsequently, the corrected data were processed to eliminate the latitude effect using the International Gravity Formula [GRS, 1980]:

$$
\text { gt }=978032.677\left(1+0.005302224 \sin ^{2} \varphi-0.000005824 \sin ^{2} 2 \varphi\right)
$$

where $\varphi$ is the latitude and gt is in mGal.

In order to obtain both the free air (fa) and the Bouguer (B) anomalies we used the standard formulas:

$$
\begin{gathered}
\Delta g_{\text {fa }}[\mathrm{mGal}]=0.3086 \mathrm{~h} \\
\Delta \mathrm{g}_{\mathrm{B}}[\mathrm{mGal}]=0.04191 \rho \mathrm{h}
\end{gathered}
$$

where $\mathrm{h}$ is the station's elevation in meters and $\rho$ is the density of the layer above the reference datum, in $\mathrm{kg} / \mathrm{m}^{3}$. Using the method of Nettleton [1976], we found an average medium density of $2300 \mathrm{~kg} / \mathrm{m}^{3}$ for the Bouguer density reduction. 

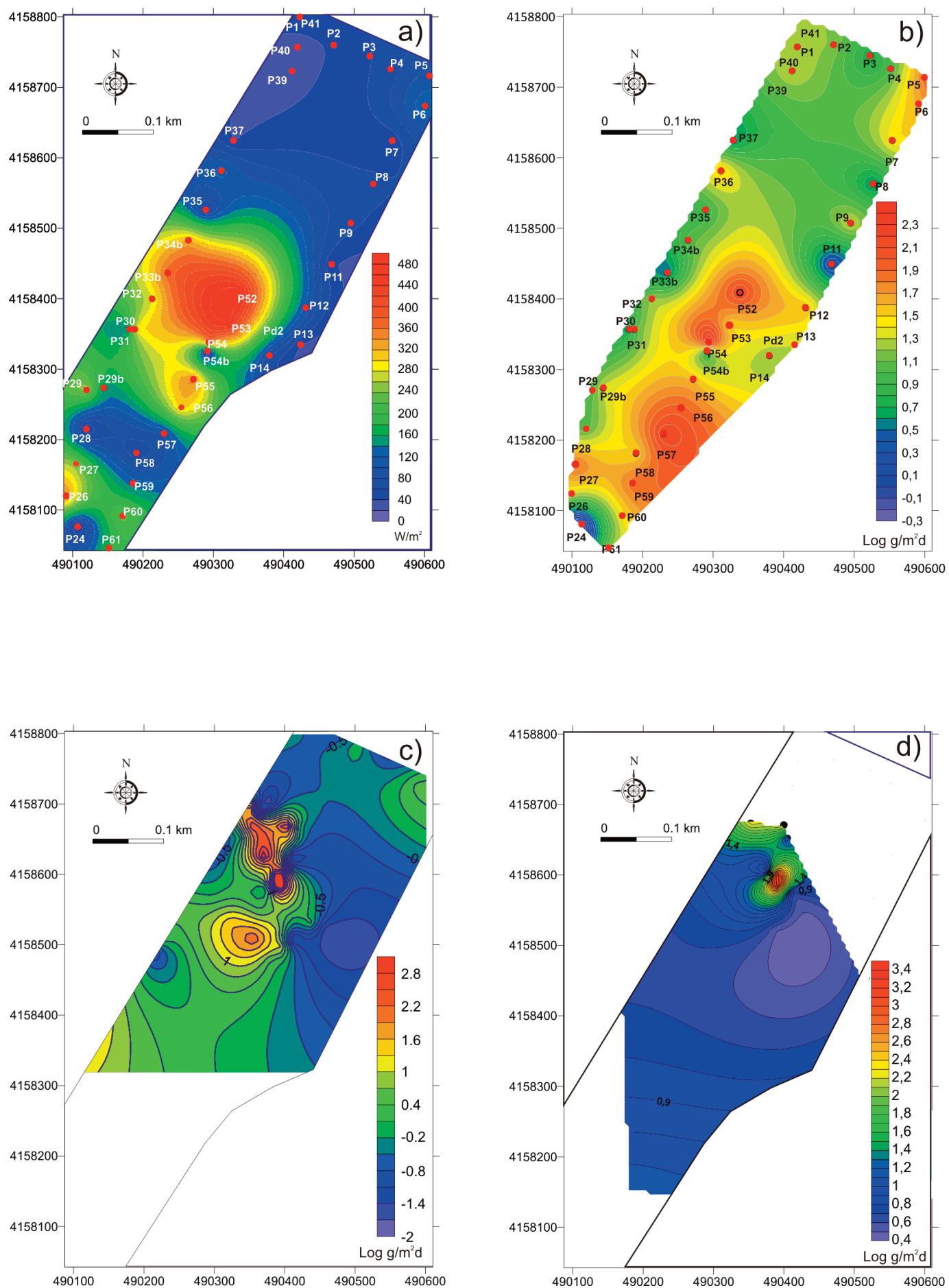

Figure 3. Shallow soil heat fluxes a) and soil $\mathrm{CO}_{2}$ effluxes b) in 40 sites distributed along two parallel profiles. Soil $\mathrm{CO}_{2}$ effluxes measurements gathered near our study area in July 2005 c) and in June 2006 d). 
Data were also corrected for the local topography using a digital elevation model with horizontal and vertical resolution of 30 and $5 \mathrm{~m}$, respectively. The correction was carried out following the procedure developed by Hammer [1939].

The Bouguer gravity anomaly values (Figure 4) in this small area vary within $2.0 \mathrm{mGal}$ (from 48 to $49.5 \mathrm{mGal}$ ). The lower gravity values are observed at the Conetto dei Cappuccini, where a well-defined, though small, anomaly is evident, while higher gravity values characterize the largest gas exhalation zone and the water/mud vents. No other significant anomalies were observed.

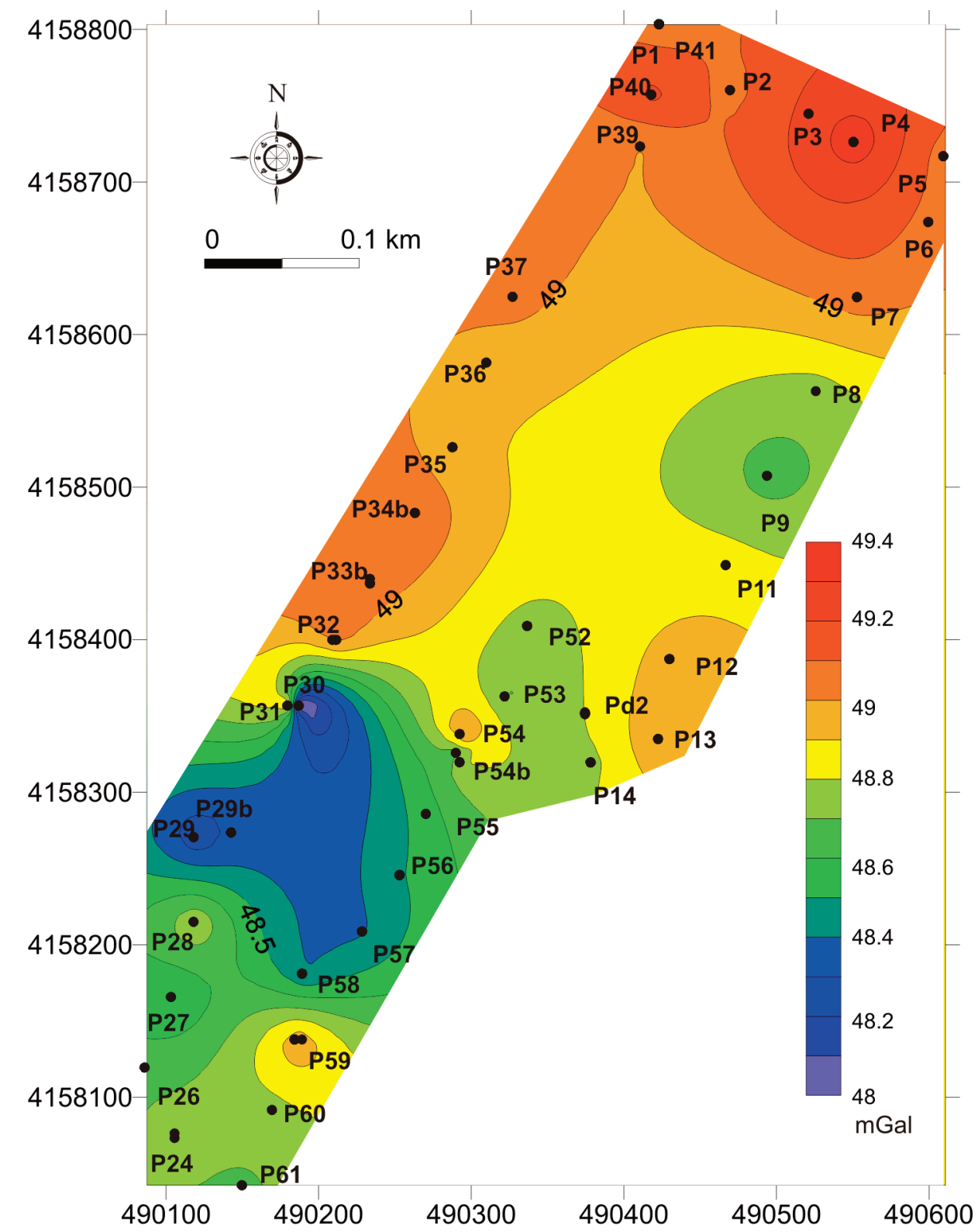

Figure 4. Bouguer anomaly map (density $2.30 \mathrm{~g} / \mathrm{cm}^{3}$ ). The free air correction was performed using the theoretical values of $0.3086 \mathrm{mGal} / \mathrm{m}$. Contour interval of $0.05 \mathrm{mGal}$. Measurement points are the same as soil $\mathrm{CO}_{2}$ efflux and soil heat flux surveys. 


\section{Rosalba Napoli et al.}

\subsection{Magnetic survey}

The magnetic survey was performed by a GSM19 Overhauser Effect magnetometer with a resolution of $0.01 \mathrm{nT}$, whose sensor was set vertically on an aluminum pole, $2 \mathrm{~m}$ above the ground surface to reduce noise. More than 2,300 measurements were gathered and georeferenced, by GPS data simultaneously collected, on a surface of about $0.45 \mathrm{~km}^{2}$ (Figure 1). To remove the time variations of external origin we used magnetic data continuously recorded by a reference station temporarily installed near the investigated region, in an area of low magnetic gradient. It is worth noting that the magnetic survey was executed during quiet days (K index values were less than 2). This allowed for a sufficient removal of transient variations from external sources, so that a suitable accuracy could be achieved. The observed magnetic field was not reduced with respect to the IGRF reference field, because of the limited extent of the investigated area. In fact, in a relatively small survey area the removal of IGRF is not significant because of its low resolution and spatial uniformity [Kearey and Brooks, 1991]. The total-intensity anomaly field, obtained after data reduction, is characterized by anomalies with variable intensity and spatial extension. In particular, small magnetic anomalies are detected within the area affected by mud volcanoes, but wider and more intense anomalies are located in the southeast and northeast parts of the investigated area. Taking advantage of the very short sampling step adopted $(2 \mathrm{~m})$ with respect to the real resolution of the survey, a low-pass filter with a cutoff wavelength of $70 \mathrm{~m}$ was applied to reduce the high frequency noise and to enhance the effects either of deep-seated bodies or of broad shallow sources. The resulting filtered magnetic map (Figure 5) reveals a manifold distribution of local magnetization. The area affected by mud volcanoes is characterized by a magnetic high surrounded by negative anomalies of smaller scale. A magnetic low is observed in the central part of the map, close to the old football stadium (Figure 1) and coincident with an old emissive area no longer active. An intense minimum, NorthSouth elongated, is observed in the southeastern part of the map, where no emissive activity has been observed so far. This magnetic signature could be related to the low magnetization of sedimentary rocks outcropping in the study area (Figure1), as reported in the geological scheme proposed by Carveni et al. [2001]. The sharp contact between high- and low-magnetized rocks (i.e., lavas and clays, respectively) could be related to the presence of a non-outcropping subsurface tectonic structure with North-South direction. Other zones of magnetic low, likely related to the presence of sedimentary rocks at shallow depth [Carveni et al., 2001], spread along the western and northern edges of the study area, but they are not completely defined since they continue where no measurements were carried out.
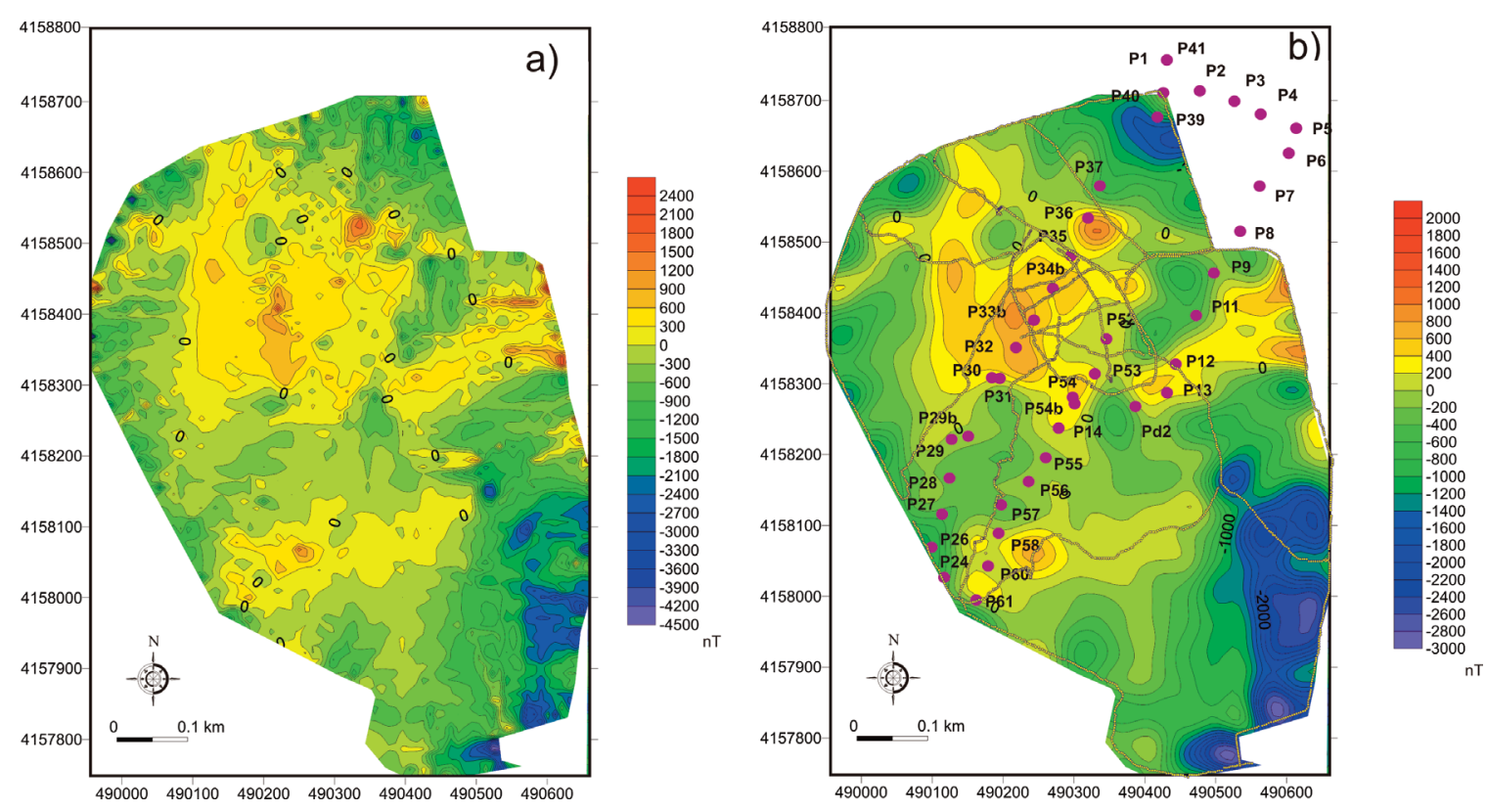

Figure 5. a) Total field magnetic anomaly map of the Salinelle area. b) Map of the local residual anomalies produced by filtering total field. The red dots indicate the measurements of soil $\mathrm{CO}_{2}$ efflux, soil heat flux and gravity surveys. The yellow lines represent magnetic measurements. 


\subsection{Self-Potential measurements}

Self-potential (SP) measurements were acquired at the same sites as the $\mathrm{CO}_{2}$ efflux, heat flux and gravity measurements (Figure 1) using a pair of $\mathrm{Cu} / \mathrm{CuSO}_{4}$ non-polarizing electrodes and an insulated electric cable. The SP method consists of measuring the difference of electrical potential between a reference electrode (arbitrarily placed at the beginning of the profile, several tens of meters away from the mud volcanoes) and a mobile electrode, using a high-impedance voltmeter (sensitivity of $0.1 \mathrm{mV}$, internal impedance of $100 \mathrm{MW}$ ). In order to improve the electrical contact between the electrode and the ground, a small hole, generally $10 \mathrm{~cm}$ deep, was dug at each site and the electrode inserted in it. Closures of the profiles were made as frequently as possible to warrant an error lower than $10 \mathrm{mV}$. The Kirchoff law is used to remove the drift of electrodes inside a loop of measurements [e.g., Revil and Jardani, 2013]. Considering the low temperature of the soil when SP measurements were gathered, we rule out that drops due to a Rapid Fluid Disruption effect [Johnston et al., 2001] affected the measurements, which, indeed, appeared stable. Finally, SP measurements in the survey area were not affected by the elevation effect because differences in the elevations among the benchmarks is negligible.

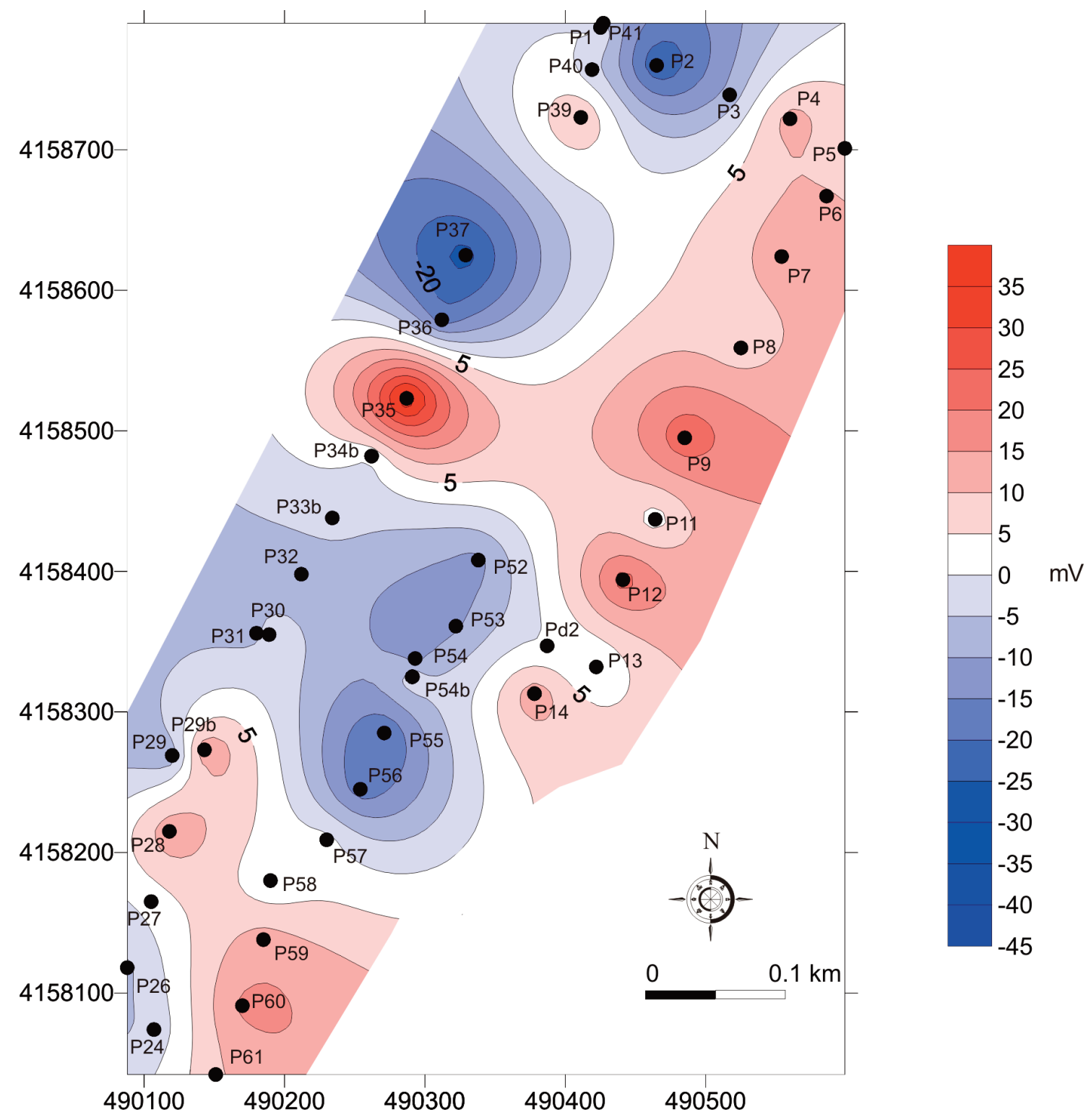

Figure 6. Spatial distribution of self-potential values in the Salinelle area. Measurement points are the same as those of soil $\mathrm{CO}_{2}$ efflux, soil heat flux and gravity surveys. 


\section{Rosalba Napoli et al.}

The SP anomaly map (Figure 6) was obtained by automatic interpolation using a kriging method and a 5-m square mesh for gridding. The SP amplitudes range from $-45 \mathrm{mV}$ to $+35 \mathrm{mV}$ (Table 1) with an average of $-10.2 \mathrm{mV}$ and standard deviation of $0.6 \mathrm{mV}$. The generally low values likely reflect the low eruptive activity of the Salinelle at the time of surveys. The SP anomaly map shows the highest negative values (down to $-45 \mathrm{mV}$ ) in the north-west part of the investigated area and the highest positive values south of the negative anomaly. Such distribution describes a clear electrical dipole extending over a distance of some tens of meters, very close to the active emissive area at the base of the Conetto dei Cappuccini. On moving southward, a larger negative anomaly is observed. Similar dipole patterns were observed in other studies focused on SP anomalies in volcanic areas [Zlotnicki et al., 2003; Lenat, 2007; Maucourant et al., 2014] and were interpreted as due to convective cells of hot fluids [Michel and Zlotnicki, 1998]. Positive anomalies of smaller magnitude characterize the eastern area, near the old football stadium, in correspondence with the old emissive area.

\section{Discussion and Conclusions}

Comparison of the results from geochemical and geophysical surveys in the Salinelle area, although quite complex, allowed us to infer the overall spatial pattern of the fluid flow processes that are acting in the study area. As a general remark, an interesting spatial correspondence was evident among soil $\mathrm{CO}_{2}$ efflux, heat flux and gravity variations. Actually, all three parameters show no significant anomaly in the northern half of the study area, whereas a greater variability with marked anomalies occurred in the central and southern half. Some of the highest values both of soil $\mathrm{CO}_{2}$ efflux and heat flux were measured at the southwestern edge of the main active mud vents area, in correspondence of the northwest slope of the Conetto dei Cappuccini. A similar pattern is evident also from the gravity anomaly map, showing the lowest gravity values in correspondence of the Conetto dei Cappuccini. These most likely are related to the presence of mass deficit or decreased rock density due to a high percentage of porosities/voids in the outcropped lava flows. Furthermore, this area corresponds remarkably well with the largest negative SP anomaly. Generally, in volcanic areas, negative SP values indicate downward motion of fluids, whereas positive values indicate areas of preferential up-rise of fluids [Jackson and Kauahikaua, 1987]. Considering the correspondence between anomalous low gravity and negative SP values, we suppose that this area marks the position of a preferential pathway for meteoric water infiltration, which contributes to the local circulation of underground fluids. In this sense, the geologic structure of the Conetto dei Cappuccini may constitute a high permeability crustal zone acting as preferential shallow pathway for the circulation of fluids.

Conversely, the zone corresponding with the main vents of gas and mud/water emission is characterized by higher gravity values, which seems in contrast to what it is normally expected. Actually, in such a context the gas emission would enlarge the pores in soft near-surface sediments, as well as contribute to widening of the gas channeling fractures. Therefore, these phenomena should produce zones with lower density values within the sediment rock and hence low gravity values at the surface. On the basis of the high gravity values, which could be ascribable to the presence of local higher density subsurface bodies (e.g., compact mudstones with low porosity), we exclude the occurrence of such phenomena and suppose the gas rises from deep through channeling fractures in the shallow impermeable layers. This is supported also by the spatial distribution of soil $\mathrm{CO}_{2}$ efflux and soil heat flux. Their similar patterns, indeed, strengthen the role of high-enthalpy fluids in carrying both mass and heat up to the surface in the Salinelle area. However, in some points, like P57 to P59 in Figure 3, high $\mathrm{CO}_{2}$ flux correspond to low heat flux. This discrepancy is likely the result of the low permeability of the soil at relatively shallow depth. The shallowest layer of soil is mostly made of low-permeability clays that are locally affected by desiccation cracking. Therefore, the hydrothermal fluid rich in $\mathrm{CO}_{2}$ propagates toward the surface following all possible high-permeability paths formed by cracks and/or other discontinuities. During this process, the fluid cools down, possibly condensate and reaches the surface as "dry" $\mathrm{CO}_{2}$-rich gas at places that sometimes can be quite far from the main deeper pathways. This "dispersion effect" of soil gas was already observed on Mt. Etna and discussed as regards soil $\mathrm{CO}_{2}$ emissions across and along the Pernicana fault system on the northeast flank of Mt. Etna [Giammanco et al., 1997; Azzaro et al., 1998].

Considering the spatial distribution of the geophysical anomalies, the investigated area appears divided into two main sectors, whose sharp contact may delineate a geologic or tectonic structure with an approximately North West-South East direction, that could justify the elongation in the same direction of the area affected by the main eruptive vents (Figure 1). This could be related to the actively growing anticline, rooted at shallow depth, that uplifts 


\section{Imaging the Salinelle Mud Volcanoes}

at a rate of about $10 \mathrm{~mm} / \mathrm{yr}$ producing ground deformation evident in the whole southern periphery of the volcano, including the Salinelle area and that is related to the gravitational spreading of the east and southeast flanks of the volcano [Bonforte et al., 2011].
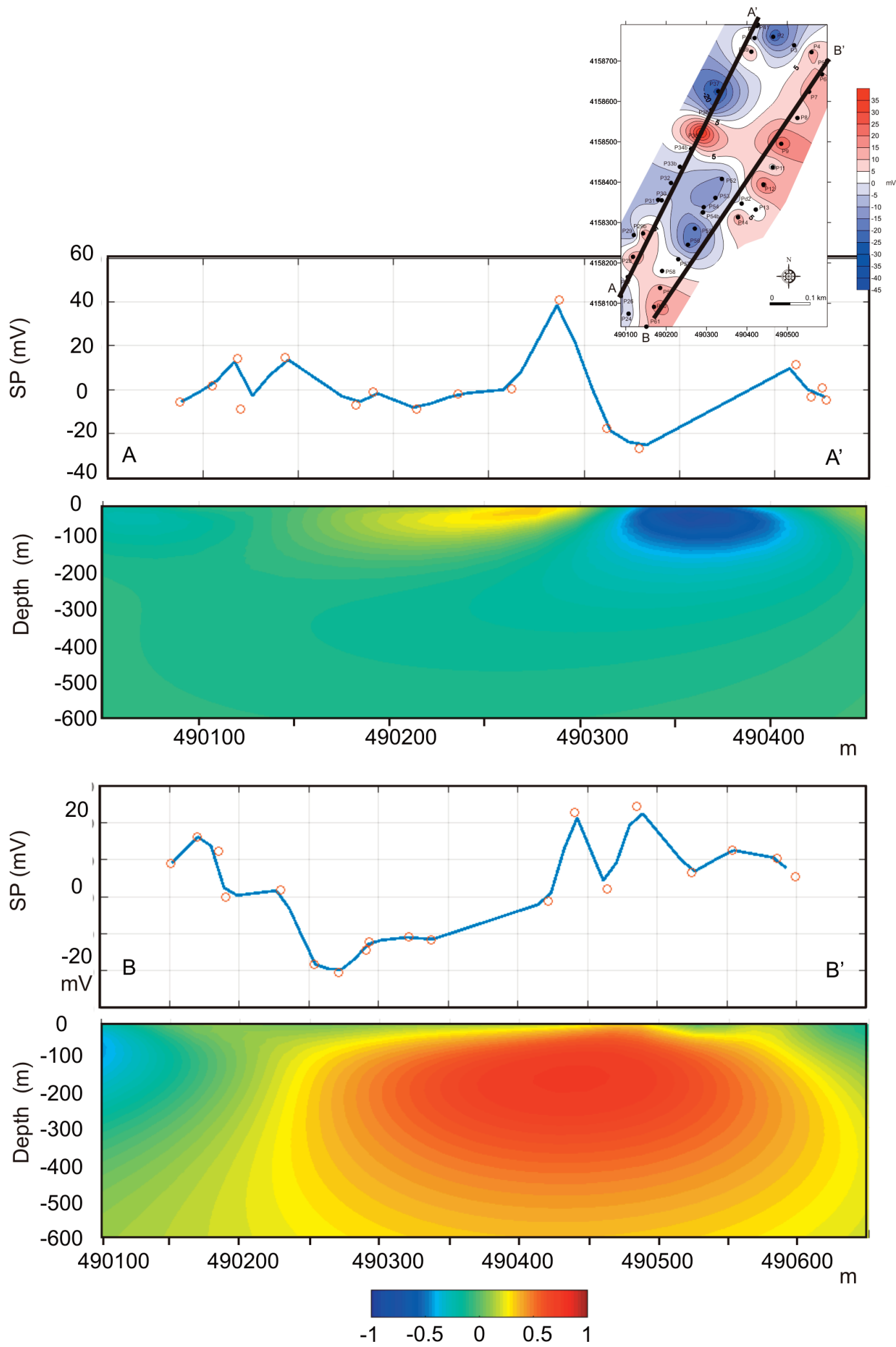

Figure 7. Dipole occurrence probability tomography of the self-potential sources along the AA' and BB' profile (shown in inset box on top right). 


\section{Rosalba Napoli et al.}

It is reasonable to suppose, therefore, that the active local tectonics may play a major role in governing the circulation of fluids in the study area and in particular favoring the escape of deep fluids toward the surface. Probably, those tectonic structures are the same deep faults that allowed magma to erupt at the surface at the time of the formation of the volcanic centers of the Conetto dei Cappuccini, Cono di Paternò (outside the investigated area) and the Ellittico Eruptive Centers lava flows. In the eastern part of the investigated area, although no temperature and gravity anomalies were detected, several small positive SP anomalies appear, corresponding to upward-migrating fluids, and overlap quite well with magnetic lows. Since the spatial distribution of these anomalies is coincident with the old area of emissive vents close to the old football stadium, the reduced magnetization zone can be ascribable to strong hydrothermal alteration of the host rocks. This is supported by the lower gravity values observed in the same area in correspondence of P9 and P11 benchmarks, probably related to clay minerals and leaching produced by hydrothermal alteration. The magnetic anomaly map does not reveal other magnetic lows in the area of the active mud volcano. In agreement with the relatively low temperature values $\left(100-150^{\circ} \mathrm{C}\right)$ calculated for the equilibration of the fluids emitted at the Salinelle, based on gas and liquid geothermometry at depth of about $1000 \mathrm{~m}$ [Chiodini et al., 1996], and measured at water outlet (40$50^{\circ} \mathrm{C}$ ), this result seems to rule out demagnetization of local rocks induced by high temperature, because this process requires temperature values higher than $500^{\circ} \mathrm{C}$. On the other hand, the observed magnetic highs can be related to the presence of lava flows of the Ellittico Eruptive Centers erupted from the Conetto dei Cappuccini [Romano et al., 1979].
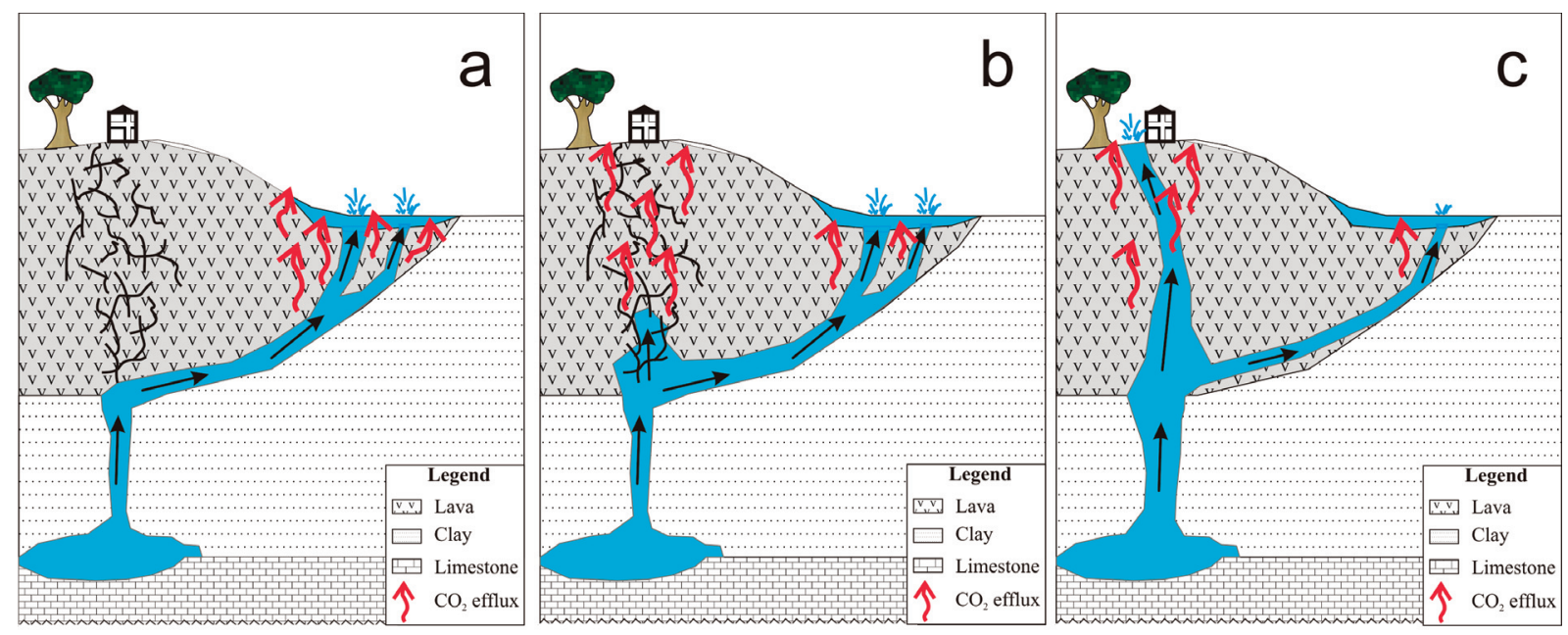

Figure 8. Schematic interpretative model of the Salinelle feeder system during normal periods of activity (a), during periods of pressure build-up in the deep reservoir of hydrothermal-hydrocarbon fluids (b) and during peripheral paroxysmal eruptions (c). Geologic section based on data form Carveni et al (2001) and Panzera et al. (2016).

Despite the presence of hot fluids in the study area, the amplitudes of the SP anomalies are remarkably low. Amplitudes ranged between -45 and $+40 \mathrm{mV}$, whereas generally in volcanic environments SP anomalies show amplitude greater than several hundreds of $\mathrm{mV}$ [Maucourant et al., 2014]. In the case of Salinelle area, the low SP values could be reasonably due either to the weak eruptive activity of the mud volcanoes when surveys were performed or to the own characteristics of the hydrothermal system related to the local properties of medium and fluids. Considering the small size of SP dipoles depicted at the surface in the studied area, the depth of the corresponding hydrothermal system is probably very shallow [Revil et al., 1999; Zlotnicki and Nishida, 2003].

In order to better identify the depth location of SP sources, a dipolar tomography [Patella, 1997; Revil et al., 2014] was applied to the SP profiles AA' and BB'. The concept of probability of charge occurrence is generally used for the tomographic imaging of the charge distribution responsible for the electric current circulation in conductive rocks [Patella, 1997]. In our case, this concept allowed us to recover the dipolar occurrence probability of the source of the dipole responsible for the observed anomalies (Figure 7). The most evident 
effect is the well-defined separation between zones with negative and positive charge occurrence probability, which appears in profile AA' at depth of about $100 \mathrm{~m}$ below the ground surface. The shallow negative source would outline the position of a main path for meteoric water infiltration, located just north of the active emissive vents. The positive source would instead indicate the sites of thermal fluids up-rise. The remarkable wide and deep positive anomaly along the BB' profile would correspond closely to the area of old emissive vents. No other occurrence probability zones are evident at depth greater than $200 \mathrm{~m}$.

The geophysical features outlined by our surveys might thus represent the signature of a very shallow convective hydrothermal system located just a few tens of meters below the ground surface. Geophysical surveys did not reveal a clear preferential pathway through which gases composed of deep $\mathrm{CO}_{2}$ of magmatic origin, revealed by geochemical surveys, can rise toward the surface. Therefore, it is likely that the hydrothermal uprise system, which regulates the activity of the Salinelle mud volcanoes, is not composed of a single feeding conduit but rather of a combination of several interconnected channels that branch at different depths, according to the stratigraphic sequence described by Panzera et al. [2016]. This interpretation is supported by the observed frequent migration of the emission vents over time, especially during paroxysmal events, although within the geological limits of the Ancient alkaline centers lavas. In fact, the main degassing vents are usually located on the northern slope of the Conetto dei Cappuccini, but emissions may occasionally migrate some hundred meters away. For example, in the past, the emission vents moved toward the old football stadium, which was damaged because of corrosion and weakening of concrete in its structure and it was consequently abandoned. More recently, in early 2016 new vents opened beneath and around a private house located at the southwest corner of the study area, producing a violent and long-standing mud eruption (Figure 2). In a similar way, in early 1990 a strong paroxysmal eruption built the largest mud cone in the area, located close to the 2016 vents [S. Giammanco, unpublished data]. In these occasions, normally the activity in the main degassing vents is strongly reduced, thus supporting the hypothesis of a change in the pathways of fluids coming from the deep feeding system. In support of this observation, soil $\mathrm{CO}_{2}$ efflux measurements previously carried out in or near our study area both in July 2005 [Giammanco et al., 2007] and in June 2006 (Messina, 2006) indicate a distribution of anomalous values mostly concentrated in the central and north part of the area (Figures 3c-d), close to the geological limit between lavas and clays (Figure 1). The different distribution of $\mathrm{CO}_{2}$ efflux values in time, therefore, suggests that in the summer of 2015 the diffuse degassing activity shifted towards the southern part of the area, very close to the sites where the new mud vents opened in early 2016.

Linking together the results from the different disciplines involved in this study, a conceptual model can be produced, which highlights the important role of local geology (Figure 8). We infer that the clay layers, outcropping in the northern part of the investigated area, represent an impermeable barrier that forces the deep fluids to rise to the surface either along the limit with the more permeable Ancient alkaline centers lavas or south of it, in any case within the lava formation. Based on the distribution of diffuse $\mathrm{CO}_{2}$ emissions, it seems that in periods of relatively mild degassing the emission of fluids is mostly concentrated in the zone where the main mud vents are usually located, which clearly represent pathways of easier uprise of fluids (Figure 8a). In periods of increased activity, supposedly related with overpressure of gas at depth, emission of fluids mostly moves towards the Conetto dei Cappuccini, thus probably forcing open pathways that are normally not used by deeper fluids to reach the surface (Figures $8 b-c$ ), though being high-permeability zones as interpreted from the geophysical surveys.

Both geochemical and geophysical mapping concurrently highlighted surficial areas of outflow and inflow of fluids, although no information can be obtained from our methods on the deep feeding hydrothermal system, due to the low spatial resolution and small extent of our measurements.

Careful definition of in situ properties of rocks and fluids, repetition of all surveys carried out during this study, especially under different "eruptive" conditions (both lower and higher emissivity at vents), enlargement of the survey area and improvement in the spatial resolution of measurements will help to improve our understanding of the hydrothermal system feeding the Salinelle mud volcanoes, especially at deeper levels.

This multidisciplinary method, obtained from high-speed and low-cost surveys, could represent a meaningful approach to monitor the spatial/temporal evolution of a hydrothermal system. In particular, in areas where hydrothermal fluids rich in mud occur in the close proximity of populated areas (such as the case of the Salinelle), our approach is intended to provide helpful and timely information on the potential migration of the fluids towards high-risk areas. Furthermore, it can be applied to other mud volcanoes where the carrier gas 


\section{Rosalba Napoli et al.}

is mostly methane and hence where the chance of gas explosions is higher (e.g., the Macalube of Aragona in southern Sicily, where two kids were recently killed by an explosion of methane and mud). This type of study contributes to the assessment and possibly mitigation of the hazard posed by this type of natural gas emissions.

Acknowledgments. We thank the Municipality of Paternò for letting us work into the state property where the Salinelle mud volcanoes are located. S.G. benefited from the financial support of CNR/DTA-INGV Agreement "Caratterizzazione di risorse geotermiche delle Regioni del Mezzogiorno d'Italia”, within the project "Atlante Geotermico delle Regioni Mezzogiorno". We thank the Editor Paola De Michelis and the anonymous referee for their constructive reviews. Contact the corresponding author for the access to the data.

\section{References}

Ahrens, L.H. (1954). The lognormal distribution of the elements (A fundamental law of geochemistry and its subsidiary). Geochim. Cosmochim. Acta 5: 49-73.

Aiuppa A., P. Allard, W. D’Alessandro, S. Giammanco, F. Parello, and M. Valenza (2004). Magmatic gas leakage at Mount Etna (Sicily, Italy): relationships with the volcano-tectonic structures, the hydrological pattern and the eruptive activity, in: Mt. Etna: Volcano Laboratory. A.G.U. Geophysical Monograph Series 143, pp. 129-145, doi:10.1029/143GM09.

Azzaro, R., S. Branca, S. Giammanco, S. Gurrieri, R. Rasà and M. Valenza (1998). New evidence for the form and extent of the Pernicana Fault System (Mt. Etna) from structural and soil-gas surveying, J. Volcanol. Geotherm. Res., 84, 143-152.

Blaikie, T.N., L. Ailleres, P.G. Betts and R.A.F. Cas (2014). Interpreting subsurface volcanic structures using geologically constrained 3-D gravity inversions: examples of maardiatremes, Newer Volcanics Province, southeastern Australia, J. Geophys. Res. Solid Earth 119, 3857-3878, http://dx.doi.org/10.1002/2013JB010751.

Bonforte, A., F. Guglielmino, M. Coltelli, A. Ferretti, and G. Puglisi (2011). Structural assessment of Mount Etna volcano from Permanent Scatterers analysis, Geochem. Geophys. Geosyst., 12, Q02002, doi:10.1029/2010GC003213.

Branca, S., M. Coltelli and G. Groppelli (2011a). Geological evolution of a complex basaltic stratovolcano: Mount Etna, Italy, Ital. J. Geosci. 130 (3), 306-317, http://dx.doi.org/10.3301/IJG.2011.13.

Branca, S., M. Coltelli, G. Groppelli and F. Lentini (2011b). Geological map of Etna volcano, 1:50,000 scale, Ital. J. Geosci. 130 (3), 265-291, http://dx.doi.org/10.3301/IJG.2011.15.

Bristow, K.L., R.D. White and G.J. Kluitenberg (1994). Comparison of single and dual probes for measuring soil thermal properties with transient heating, Australian J. Soil Res. 32, 447-464.

Bruijn P.J., I.A. van Haneghem and J. Schenk (1983). An improved nonsteady-state probe method for measurements in granular materials, Part 1: Theory, High Temp. High Press. 15, 359-366, 1983.

Cangemi, M. and P. Madonia (2014). Mud volcanoes in onshore Sicily: a short overview, in: Wiese, F.; Reich, M. \& Arp, G. (eds.): Spongy, slimy, cosy \& more.... Commemorative volume in celebration of the 60th birthday of Joachim Reitner. Göttingen Contributions to Geosciences 77: 123-127.

Caracausi, A., F. Italiano, A. Paonita, A. Rizzo and P.M. Nuccio (2003). Evidence of deep magma degassing and ascent by geochemistry of peripheral gas emissions at Mount Etna (Italy): Assessment of the magmatic reservoir pressure, J. Geophys. Res. 108, B10, 2463, doi:10.1029/2002JB002095.

Carveni P., S. Benfatto and G. Sturiale (2001). Aspetti geologici e geomorfologici dei vulcani di fango del basso versantesud-occidentale etneo ed ipotesi sulla loro genesi, Il Quaternario, 14 (2), 117-130.

Carveni P., F. Barone, S. Benfatto, S. Imposa and G. Mele (2012). Mud volcano fields in the Mt. Etna area (eastern Sicily), in: C. Giusti (Ed.), Geomorphosites 2009: raising the profile of geomorphological heritage through iconography, inventory and promotion, Paris Sorbonne Université, Paris, pp. 54-60.

Chiodini G., W. D’Alessandro and F. Parello (1996). Geochemistry of the gases and of the waters discharged by the mud volcanoes of paternò, Mt. Etna (Italy), Bull. Volcanol., 58, 51-58.

Chiodini G., G. Cioni, R. Guidi, M. Raco, and B. L Marini (1998). Soil $\mathrm{CO}_{2}$ flux measurements in volcanic and 
geothermal areas, Appl. Geochem. 13, 135-148.

D’Alessandro W., F. Parello, and M. Valenza (1996). Gas manifestations of Mt Etna area: historical notices and new geochemical data (1990-93), Acta Vulcanol. 8(1), 23-29.

Etiope G., A. Caracausi, R. Favara, F. Italiano and C. Baciu (2002). Methane emission from the mud volcanoes of Sicily (Italy), Geophys. Res. Lett., 29 (8), 1215, doi:10.1029/2001GL014340, 2002.

Federico, C., M. Liuzzo, G. Giudice, G. Capasso, A. Pisciotta and M. Pedone (2019). Variations in $\mathrm{CO}_{2}$ emissions at a mud volcano at the southern base of Mt Etna: are they due to volcanic activity interference or a geyserlike mechanism? Bull. Volcanol., 81:1, DOI:10.1007/s00445-018-1261-x.

Ferrara, V. and G. Pappalardo (2008). The hydrogeological map of the Etna volcanic massif as useful tool for groundwater resources management, International Journal for Engineering Geology and the Environment 1, 77-89 (Special Issue).

Giammanco S., K.W.W. Sims and M. Neri (2007). Measurements of 220Rn and 222Rn and $\mathrm{CO}_{2}$ emissions in soil and fumarole gases on Mt. Etna volcano (Italy): Implications for gas transport and shallow ground fracture, Geochem. Geophys. Geosys., 8(10), doi:10.1029/2007GC001644.

Giammanco S., S., Gurrieri and M. Valenza (1995). Soil $\mathrm{CO}_{2}$ degassing on Mt. Etna (Sicily) during the period 1989-1993: discrimination between climatic and volcanic influences. Bull Volcanol 57(1):52-60

Giammanco, S., S. Gurrieri and M. Valenza. (1997). Soil $\mathrm{CO}_{2}$ degassing along tectonic structures of Mount Etna (Sicily): the Pernicana fault, Appl. Geochem., 12: 429-436.

Giammanco S and P. Bonfanti (2009). Cluster analysis of soil $\mathrm{CO}_{2}$ data from Mt. Etna (Italy) reveals volcanic influences on temporal and spatial patterns of degassing. Bull Volcanol 71(2):201-218.

Giammanco, S., S. Carbone and A. Pistorio (2016). Il Geosito "Sistema delle Salinelle del Monte Etna" (Paternò e Belpasso - Sicilia orientale), Geologia dell'Ambiente 3/2016, 42-46.

Greco F., G. Currenti, G. D’Agostino, A. Germak, R. Napoli, A. Pistorio, and C. Del Negro (2012). Combining relative and absolute gravity measurements to enhance volcano monitoring at Mt Etna (Italy). Bull Volcanol. doi:10.1007/s00445-012-0630-0.

Greco F., S. Giammanco, R. Napoli, G. Currenti, A. Vicari, A. La Spina, G. Salerno, L. Spampinato, A. Amantia, M. Cantarero, A. Messina and A. Sicali (2016). A multidisciplinary strategy for in-situ and remote sensing monitoring of areas affected by pressurized fluids: application to mud volcanoes, IEEE Sensors Applications Symposium (SAS 2016) Proceedings, pp 291-296.

Inguaggiato, S., I.S. Diliberto, C. Federico, A. Paonita, and F. Vita (2018). Review of the evolution of geochemical monitoring, networks and methodologies applied to the volcanoes of the Aeolian Arc (Italy), Earth Sci. Rev. 176, 241-276. http://dx.doi.org/10.1016/j.earscirev.2017.09.006.

Hammer, S. (1939). Terrain corrections for gravimeter stations,. Geophysics, 4(3), 184-194.

Hashimoto, T. and Y. Tanaka (1995). A large self-potential anomaly at Unzen volcano, Shimabara Peninsula Kyushu Island, Japan. Geophys. Res. Lett. 22, 191-194.

Jackson, D.B. and J. Kauahikaua (1987). Regional self-potential anomalies at Kilauea Volcano, in: Decker, R.W., Weight, T.L., Stauffer, P.H. (Eds.), Volcanism in Hawaii, U.S. Geol. Surv. Prof. Paper, 1350, 2, 40, pp. 947-959.

Johnston, M.J.S., J.D. Byerlee and D. Lockner (2001). Rapid fluid disruption: a source for self-potential anomalies on volcanoes, J. Geophys. Res. 106 (B3), 4327-4335.

Kearey P and M. Brooks (1991). An introduction to geophysical exploration, Second edn. Blackwell Scientific Publications, Oxford, $254 \mathrm{pp}$

Kopf, A. J. (2002). Significance of mud volcanism. Reviews of Geophysics 40: 2-1-2-52. http://dx.doi.org/10.1029/2000RG000093.

Lenat, J.F. (2007). Retrieving self-potential anomalies in a complex volcanic environment: an SP/elevation gradient approach, Near Surf. Geophys. 5, 161-170.

Maucourant, S., S. Giammanco, F. Greco, S. Dorizon and C., Del Negro (2014). Geophysical and geochemical methods applied to investigate fissures-related hydrothermal systems on the summit area of Mt. Etna volcano, J. Volcanol. Geotherm. Res., 280, 111-125. doi:10.1016/j.jvolgeores.2014.05.014.

Mauri, G., G. Williams-Jones, G., Saracco and J.M. Zurek (2012). A geochemical and geophysical investigation of the hydrothermal complex of Masaya volcano, Nicaragua, J. Volcanol. Geotherm. Res. 227-228, 15-31. http://dx.doi.org/10.1016/j.jvolgeores.2012.02.003. 


\section{Rosalba Napoli et al.}

Messina, G.R.(2006). Rilevamento geologico e geochimico dell'area di Paternò. Ms. Thesis, University of Catania, $72 \mathrm{pp}$.

Michel, S. and J., Zlotnicki (1998). Self-potential and magnetic surveying of La Fournaise volcano (Réunion Island): correlations with faulting, fluid circulation, and eruption, American Geophysical Union, Paper number 98JB00607. 0148-0227/98/98JB-00607509.00.Nettleton 1976

Napoli, R., G. Currenti and C. Del Negro (2007). Internal structure of Ustica volcanic complex (Italy) based on a 3D inversion of magnetic data, Bull. Volcanol. http://dx.doi.org/10.1007/s00445-007-0115-8.

Napoli, R. and G. Currenti. (2016). Reconstructing the Vulcano Island evolution from 3D modelingof magnetic signatures, J. of Volcan. Geother.Res. 320, 40 - 49, doi:10.1016/j.jvolgeores.2016.04.011.

Nickschick, T., H. Kampf, C. Flechsig, J. Mrlina and J. Heinicke (2015). $\mathrm{CO}_{2}$ degassing in the Hartousov mofette area, western Eger Rift, imaged by $\mathrm{CO}_{2}$ mapping and geoelectrical and gravity surveys, Int. J. Earth Sci. DOI:10.1007/s00531-014-1140-4.

Panzera F., S. Sicali G. Lombardo S. Imposa S. Gresta and S. D’Amico (2016). A microtremor survey to define the subsoil structure in a mud volcanoes area: the case study of Salinelle (Mt. Etna, Italy), Environ Earth Sci 75:1140 DOI:10.1007/s12665-016-5974-x.

Paonita A (2010). Long-range correlation and nonlinearity in geochemical time series of gas discharges from Mt. Etna, and changes with 2001 and 2002-2003 eruptions, Nonlinear Process Geophys 17(6):733-751

Parello, F., W. D’Alessandro, A. Aiuppa and C. Federico (2001). Cartografia geochimica degli acquiferi etnei, CNR, Gruppo Nazionale per la Difesa dalle Catastrofi Idrogeologiche 2190, 104 pp.

Parkinson K.J. (1981). An improved method for measuring soil respiration in the field, J App Ecol 18: 221-228.

Patella D. (1997). Self-potential global tomography including topographic effects, Geophysics, Prospect., 45, 843-863.

Pecoraino, G. and S. Giammanco (2005). Geochemical Characterization and Temporal Changes in Parietal Gas Emissions at Mt. Etna (Italy) During the Period July 2000 - July 2003, Terr., Atmosph. Ocean. Sci. 16 (4), 805841.

Pistorio A, F. Greco, G. Currenti, R. Napoli, A. Sicali, C. Del Negro and L. Fortuna (2011). High precision gravity measurements using absolute and relative gravimeters at Mount Etna (Sicily, Italy), Annals Geophys. 54, 5, doi:10.4401/ag-5348.

Revil, A., P.A. Pezard, and P.W.J. Glover (1999a). Streaming potential in porous media 1. Theoryof the zeta potential. J. Geophys. Res. 104 (B9), 20021-20031.

Revil, A., H. Schwaeger, L.M. Cathles and P.D. Manhardt (1999b). Streaming potential in porousmedia 2. Theory and application to geothermal systems, J. Geophys. Res. 104 (B9), 20033-20048.

Revil A., A. Finizola, F. Sortino and M. Ripepe (2004). Geophysical investigations at Stromboli volcano, Italy: implications for ground water flow and paroxysmal activity, Geophys. J. Int., 157, 426-440.

Revil, A., A. Finizola, S. Piscitelli, E. Rizzo, T. Ricci, A. Crespy, B. Angeletti, M. Balasco, S. Barde Cabusson, L. Bennati, A. Bolève, S. Byrdina, N. Carzaniga, F. Di Gangi, J. Morin, A. Perrone, M. Rossi, E. Roulleau and B. Suski (2008). Inner structure of La Fossa di Vulcano (Vulcano Island, southern Tyrrhenian Sea, Italy) revealed by high-resolution electric resistivity tomography coupled with self-potential, temperature, and $\mathrm{CO}_{2}$ diffuse degassing measurements, J. Geophys. Res. 113, B07207. https://doi.org/10.1029/2007JB005394.

Revil, A. and A. Jardani (2013). The Self-PotentialMethod: Theory and Applications in Environmental Geosciences, Cambridge University Press.

Romano R., F. Lentini C. Sturiale C. Amore P. Atzori S.R. Carter, R. Cristofolini I. Di Geronimo A. Di Grande, A.M. Duncan, V. Ferrara, F. Ghisetti, J.E. Guest, H. Hamill, G. Patanè, A. Pezzino, D. Puglisi, F. Schilirò, G. Torre and L. Vezzani (1979). Carta geologica del Monte Etna, scala 1:50.000, Litogr. Art. Cartogr., Firenze.

Rothman L.S., C.P. Rinsland, A. Goldman, S.T. Massie, D.P. Edwards, J.M. Flaud, A. Perrin, C. Camy-Peyret, V. Dana, J.Y. Mandin, J. Schroeder, A. McCann, R.R, Gamache, R.B. Wattson, K. Yoshino, K. V. Chance, K. W. Jucks, L. R. Brown, V. Nemtchinov and P. Varanas (1998). The HITRAN molecular spectroscopic database, Journal of Quantitative. Spectroscopy and Radiative Transfer, 60, 665-710, 1998.

Schiavone D. and M. Loddo (2007). 3-D density model of Mt. Etna Volcano (Southern Italy), Geology, DOI:10.1016/j.jvolgeores.2007.04.016

Tonani F. and G. Miele (1991). Methods for measuring flow of carbon dioxide through soils in the volcanic setting, Technical report, Ist. Ann. Glob. Appl. C.N.R., Firenze, Italy. 
van Haneghem I.A., J. Schenk and H.P.A. Boshoven (1983). An improved nonsteady-state probe method for measurements in granular materials, Part II: Experimental results, High Temp. High Press., 15, 367-374, 1983.

van Loon W.K.P., I.A. van Haneghem and J. Schenk (1989). A new model for the non-steady-state probe method to measure thermal properties of porous media. Int. J. Heat Mass Transfer 32 (8), 1473-1481 .

Wenzel, H.G. (1996). The nanogal Software: Earth Tide Data Processing Package ETERNA 3.30, Bull. Inf. Marees Terrestres, Vol., 124, 9425-9439.

Zlotnicki, J., Y. Sasai, P. Yvetot, Y. Nishida, M. Uyeshima, F. Fauquet, H. Utada, Y. Takahashi and G. Donnadieu (2003). Resistivity and self-potential changes associated with volcanic activity: The July8, 2000 Miyakejima eruption (Japan), Earth Planet. Sci. Lett. 205, 139-154.

Zlotnicki, J. and Y. Nishida (2003). Review on morphological insights of self-potential anomalies on volcanoe,. Surv. Geophys. 24 (4), 291-338.

*CORRESPONDING AUTHOR: Rosalba NAPOLI,

Istituto Nazionale di Geofisica e Vulcanologia, Sezione di Catania, Osservatorio Etneo, Catania, Italy e-mail: rosalba.napoli@ingv.it (c) 2020 the Istituto Nazionale di Geofisica e Vulcanologia. All rights reserved 